\title{
Partial replacement of dietary soybean meal by high protein distiller's dried grains (HPDDG) supplemented with protease enzyme for European seabass, Dicentrarchus labrax fingerlings
}

by Goda, A.M.S., Ahmed, S.R., Nazmi, H.M., Baromh, M.Z., Fitzsimmons, K., Rossi Jr, W., Davies, S. and ElHaroun, E.

Copyright, publisher and additional information: this is the author accepted manuscript. The final published version (version of record) is available online via Wiley. This article may be used for non-commercial purposes in accordance with Wiley Terms and Conditions for Self-Archiving.

Please refer to any applicable terms of use of the publisher.

DOI: https://doi.org/10.1111/anu.13043

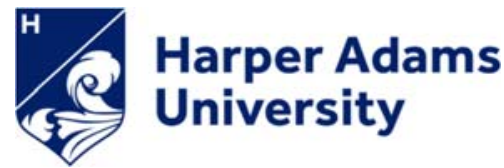


Partial replacement of dietary soybean meal by high protein distiller's dried grains (HPDDG)

2 supplemented with protease enzyme for European seabass, Dicentrarchus labrax fingerlings

3

4

5

6

7 Ashraf M.A.-S. Goda ${ }^{1}$, Sherine R. Ahmed ${ }^{1}$, Hany M. Nazmi ${ }^{1}$, Mohamed Z. Baromh ${ }^{1}$, Kevin 8 Fitzsimmons ${ }^{2}$, Waldemar Rossi $\mathrm{Jr}^{3}$, Simon Davies ${ }^{4}$, Ehab El-Haroun ${ }^{5, *}$

9

10

11

$12{ }^{1}$ Aquacultre Division, National Institute of Oceanography and Fisheries (NIOF), Alexandria, Egypt.

$13{ }^{2}$ Department of Environmental Science, University of Arizona, Tucson, Arizona, USA.

$14{ }^{3}$ School of Aquaculture and Aquatic Sciences, Kentucky State University, Frankfort, Kentucky, USA.

$15 \quad{ }^{4}$ Fish Nutrition and Aquaculture Unit, Harper Adams University, Newport, UK

$16{ }^{5}$ Fish Nutrition Research Laboratory, Faculty of Agriculture, Cairo University, Egypt.

17

18

19

20

21

$22{ }^{*}$ Corresponding author. E-mail address: elharoun@gmail.com (Ehab El-Haroun

23

24

25 
Abstract

High protein distillers dried grains (HP-DDG) is a co-product of ethanol production that uses

28

29

30

5

9
pre-fractionation technology. A 70-day's growth trial was conducted to investigate the effect of partial replacement of dietary soybean meal by high protein distiller's dried grains (HPDDG) with protease enzyme supplementation (PROXYM ULTRA ${ }^{\circledR}$ ) on growth performance, physiological parameters and histological changes of the intestine of European sea bass, Dicentrarchus labrax fingerlings. The results indicated that increase dietary HP-DDG levels up to $50 \%$ of HP-DDG-supplemented with Protease significantly increases growth performance, feed utilization and improved FCR of sea bass. In addition, replacement of SBM by HP-DDG-supplemented with protease enhanced feed intake efficiency and the health status of fish. Hematology and serum biochemistry (hemoglobin (Hb), red blood cells (RBCs), white blood cells (WBCs) and humeral immune parameters including total protein, globulin, cholesterol, lysozyme activity and total antioxidant capacity significantly increased with increase HP-DDGsupplemented with protease in the diets. Results of this study indicated that HP-DDG-supplemented with protease is a good alternative protein source for aquaculture feed and can be included up to $50 \%$ as a replacement of SBM without compromising growth performance and physiological parameters of sea bass.

Keywords: Dicentrarchus labrax, HP-DDG-supplemented with protease, physiological parameters, growth performance, feed utilization, histology, humeral immune parameters

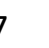

$\left(\frac{100}{20}\right.$

0


Aquaculture production is expanding to fill the increasing demand of fish for human consumption

53 globally. In 2016, aquaculture was responsible for the production of 171 million tons of fish products, most of which was for human consumption (FAO, 2018). With the world's population projected to reach 9.7 billion people by 2050 and global capture fisheries unstable and steadily declining, the spotlight turns to aquaculture production to contribute significantly to global food security and adequate global nutrition and human health (NASS, 2016). More than $70 \%$ of the total global aquaculture production is dependent upon the supply of external feed inputs. For the aquaculture sector to maintain its current growth rate, the supply of nutrient and feed inputs will have to grow at a similar rate, while aquatic ingredients production remains static and other sectors compete for same feed resources. There is an increasing need to seek alternatives, particularly underutilized commodities, such as by products obtained from food,

62 fermentation and pharmaceutical industries, rather than being highly dependent of imported plant feedstuffs (Hassaan et al 2018 a,b et al., 2018; Hassaan et al., 2019), distillers dried grains with solubles (DDGS) is a by-product of cereal distillation for ethanol production. DDGS contains high protein, lipid and low fiber and Antinutritional factors (ANFs) levels (Liu, 2011). Studies on DDGS incorporation in aqua-feeds studies were mainly done in omnivorous fish species, such as channel catfish, Ictalurus punctatus; Li et al., 2011a). Nile tilapia, Oreochromis niloticus and hybrid tilapia, Oreochromis niloticus al., 2013; Welker et al., 2014b), olive flounder, Paralichthy solivaceus (Rahman et al., 2015; Bae et al., 2015), meagre (Argyrosomus regius) and European sea bass (Magalhães et al., 2015). In addition, the use nutrients, including protein, carbohydrates and minerals (Forster et al. 1999). Earlier studies indicated 
and Carter, 2007) and improving the histological structure (Mathlouthi et al., 2002) and the health of

77 intestine (reviewed by Castillo and Gatlin, 2015). Furthermore, digestive enzyme supplementation help

\section{7} to eliminate the effects of anti-nutritional factors and improve the utilization of dietary energy and amino acids, resulting in improved growth performance (Soltan 2009). The present study was undertaken to determine the effect of various dietary levels of high protein distiller's dried grains (HPDDG) supplemented with enzyme protease on growth performance, feed utilization, histology and haematological indices of European sea bass Dicentrarchus labrax fingerlings.

\section{MATERIALS AND METHODS}

\section{Experimental Fish and Culture Technique}

European seabass, with an average initial body weight of $7.47 \pm 0.8 \mathrm{~g} /$ fish were obtained from ElShiref farm, Wady Marriott, Alexandria Governorate, Egypt; fish acclimated for one week to the water and were fed a control diet ( $5 \%$ body weight/day). During fish acclimation, the fingerlings were stocked in indoors circular fiberglass tanks ( 1 cubic meter) for one week and were fed with a control diet at a ratio of $5 \%$ of body weight $\mathrm{d}^{-1}$. The daily ration was divided into three equal amounts and offered three times a day $(09.00,12.00$ and $15.00 \mathrm{~h})$. Fish were randomly distributed into 12 glass aquaria $(70 \times 40 \times 30$ $\mathrm{cm}$ each) at El-Shiref farm, Alexandria, in a design of three replicate tanks for each of four dietary treatments. Fish were stocked at a density of 10 fish per aquaria. Water temperature, dissolved oxygen, $\mathrm{pH}$, and ammonia were monitored during the trial, to maintain water quality at optimum range for $D$. labrax. Water temperature was maintain at $18.5 \pm 0.9^{\circ} \mathrm{C}$, dissolved oxygen (DO) at $6.1 \mathrm{mg} \mathrm{L}-1$ and $\mathrm{pH}$ at $7.6 \pm 0.7$, under natural light (12:12 h light: dark schedule). Daily, $20 \%$ of water was exchange using underground filtered water (36 ppt). 
102 formulated (Table 1). The control diet $\left(\mathrm{C}_{0} \%\right)$ had no high protein distiller's dried grains (HP-DDG) or 103 Protease added.

Tested diets were formulated to contain 30\% (P30\%), 40\% (P40\%), and 50\% (P50\%) of HP-DDG 105 added on the expanses of the soybean meal content and equally supplemented with $1.0 \mathrm{~g} / \mathrm{kg}$ of Protease (PROXYM 102 ULTRA ${ }^{\circledR}$ ), HPDDG and protease in the present study are considered as a single ingredient complex. HP-DDG is one of the most competitive sources of protein due to its lower moisture content, higher levels of lysine (3\%) and longer shelf life. HPDDG supplied from United States USA, by MIRASCO EGYPT Company. The chemical composition of HP-DDG used in the rations was crude 110 protein 47\%; Crude fat 4\%; Crude fiber 4\%; Ash 7\% and Moisture 7\%. During the 70-days experimental period, all fish were fed with their respective diets at 5\% of body weight $\mathrm{d}^{-1}$ for 6 days/week. Every 14 days, fish were weighed and the daily ration was adjusted accordingly. The daily ration was divided into three equal amounts and offered three times a day (09:00, 12:00 and 15:00 h).

114 Experimental diets were individually prepared by mixing the dry ingredients with $200 \mathrm{ml}$ of water per $\mathrm{kg}$ 115 diet. Two grams of commercial protease enzyme (PROXYM ULTRA5®, Gloray Vet COMPANY, USA ) contain the enzymatic activity of 2000000 Unit was dissolved into the $200 \mathrm{~mL}$ water at $37^{\circ} \mathrm{C}$ (Yoo et al., 2005). The solution was incubated for 24 hours at room temperature according to the method of Danwitz et al. (2016) prior to its addition to the experimental diets the mixture was blended, turned into a paste and pelleted by passing the blended mixture through a laboratory pellet machine with a $1 \mathrm{~mm}$ diameter matrix. The resulting wet pellets were dried at room temperature for two days and then stored

121 in plastic bags and kept refrigerated $\left(-2^{\circ} \mathrm{C}\right)$ until use. Commercial protease enzyme product (PROXYM 122 ULTRA $^{\circledR}$ ) was purchased from Gloray Vet COMPANY, USA. One gram of commercial protease enzyme (PROXYM ULTRA5®, Gloray Vet COMPANY, USA ) contain the enzymatic activity of 2000000 Unit 124 was dissolved into $100 \mathrm{~mL}$ water at $37^{\circ} \mathrm{C}$ (Yoo et al., 2005. The solution was added to the experimental 125 diets and incubated for 24 hours at room temperature according to the method of Danwitz et al. (2016). 


\section{Growth Indices}

The mean final body weight (FBW) in experimental treatment was determined by dividing the total fish weight in each aquarium by the number of fish. Weight gain (WG), specific growth rate (SGR), feed conversion ratio (FCR), protein efficiency ratio (PER), protein productive value (PPV), fat retention (FR), energy retention (ER), economical conversion rate (ECR) and survival (\%) were calculated using the following equations, according to Tiews (1980):

$\mathrm{WG}=$ final body weight $(\mathrm{g})$ - initial body weight $(\mathrm{g})$.

$\mathrm{SGR}=100 \times[(\ln$ final body weight $(\mathrm{g})-\ln$ initial body weight $(\mathrm{g})) /$ duration of feeding (day) $]$

$\mathrm{FCR}=$ feed intake $(\mathrm{g}) /$ weight gain $(\mathrm{g})$

PER $=$ weight gain $(\mathrm{g}) /$ protein intake $(\mathrm{g})$.

$\mathrm{PPV}=($ protein gain $(\mathrm{g}) /$ protein intake $(\mathrm{g})) \times 100$

$\mathrm{FR}=($ fat gain $(\mathrm{g}) /$ fat intake $(\mathrm{g})) \times 100$.

$\mathrm{ER}=($ energy gain $(\mathrm{kJ}) /$ energy intake $(\mathrm{kJ})) \times 100$.

$\mathrm{ECR}=$ cost of diet $\left(\$ \mathrm{~kg}^{-1}\right) \times$ Feed Conversion Ratio $(\mathrm{FCR})$

Survival $(\%)=100 \times($ initial number of the fish/final number of fish) .

\section{Blood Samples and Haematological Analysis}

Blood samples were collected at the end of the experiment. From each of the dietary treatments, five fish were used for hematological indices analysis and five for plasma content analysis. The fish were anesthetized with t-amyl alcohol and the blood samples were taken by puncturing the caudal vessels. Blood samples were collected into two tubes, one containing heparin as anticoagulant agent for haematological assessment and the other was anticoagulant free for biochemical estimation. The haematological parameters are expressed in international units (SI). The total red and white blood cell counts (RBC; $10^{6} \mathrm{~mm}^{-3}$ and $\mathrm{WBC} ; 10^{3} \mathrm{~mm}^{-3}$, respectively) were obtained by using a standard Neubauerhemocytometer chamber using Shaw's solution as diluting fluid (Stoskopf, 1993). Hemoglobin (Hb; g $\mathrm{dL}^{-1}$ ) was determined colorimetrically using commercial kits (Diamond, Egypt) according to the cyan- 
methemoglobin procedure (Drabkin, 1945). Hematocrit (Hct) were determined by using

152 microhematocrit-heparinized capillary tubes and a microhematocrite centrifuge (10000 g for $5 \mathrm{~min}$ )

153 Levels of serum aspartate aminotransferase (AST), alanine aminotransferase (ALT) and alkaline

154 phosphatase (ALP) were estimated according to the method described by Reitman \& Frankel (1957).

155 Biochemical and immune parameters

The total protein $\left(\mathrm{g} \mathrm{dL}^{-1}\right)$ was determined in plasma samples of fish from the different

157 experimental groups by the Biuret method according to (Doumas et al. 1981). Albumin (g dL $\left.{ }^{-1}\right) \mathrm{was}$ 158 determined by the bromocresol green method (Reinhold, 1953) and globulin ( $\left.\mathrm{g} \mathrm{dL}^{-1}\right)$ was calculated as the difference between total protein and albumin, and cholesterol was measured by a commercial kit

160

161

162

163

164 165

(Pasteur, Lab, France, Egypt) (Yousefi et al. 2011). Lysozyme activity (U mg-1 protein) in serum was determined according to the method of Ellis (1990) based on the lysis of the lysozyme sensitive grampositive bacterium Micrococcus lysodeikticus (Sigma, St. Louis, MO). Lysozyme acts upon susceptible bacteria by combining with and breaking down a mucopolysaccharide. This mucopolysaccharidehas has been shown to be situated in the bacterial cell wall M. lysodeikticus, is normally highly sensitive to lysozyme dilutions of hen egg white lysozyme (Sigma) ranging from 0 to $25 \mu \mathrm{g} \mathrm{mL} \mathrm{L}^{-1}$ (in $0.1 \mathrm{M}$ phosphatecitrate buffer, pH 6) (Sigma, USA) were used as the standard.

Total antioxidant capacity (TAC) level was estimated spectrophotometrically at $532 \mathrm{~nm}$ following the method with Tween 80 oxidation (Galaktionova et al. 1998). Briefly, $0.2 \mathrm{ml}$ of tissue homogenate was added to $2 \mathrm{ml}$ of $1 \%$ Tween 80 . Instead of the sample, the blank assay included $0.1 \mathrm{ml}$ of distilled water. The mixture was incubated for 48 hours at $37^{\circ} \mathrm{C}$. After cooling, $1 \mathrm{ml}$ of $40 \%$ TCA was added. The mixture was centrifuged at 3,000 $\mathrm{g}$ for $10 \mathrm{~min}$. After centrifugation, $2 \mathrm{ml}$ of supernatant and $2 \mathrm{ml}$ of $0.25 \%$ TBA reagent were mixed in. The mixture was heated in a boiling water bath at $100{ }^{\circ} \mathrm{C}$ for 15 minutes. The absorbance of the solution obtained was measured at $532 \mathrm{~nm}$ and was compared with the blank. The TAC level was expressed in (\%).

\section{Histological examination}


177 for tissue removal. The intestine were removed, thoroughly washed with a physiological saline $(0.9 \%$

178 Nacl) solution and fixed in Bouin's fluid. The material was dehydrated, cleared and finally embedded in

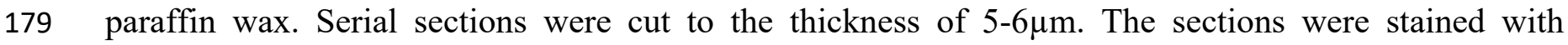
180 haematoxylin counterstained with eosin and mounted in DPX (Yano, 1988). The sections were examined 181 with an Olympus light microscope and photographed with digital camera as required. The histological 182 examination was carried out according to Culling (1983).

Economic evaluation

The economic evaluation was calculated according to the following equations (Salama et al., 2010).

185

186

187

188

189

190

191

192

193

194

195

196

197

198

199

200

Feed cost per Kg fresh fish (LE) = Cost $/ \mathrm{kg}$ diet (LE) * consumed feed to produce $1 \mathrm{~kg}$ fish .

Relative feed cost $/ \mathrm{Kg}$ fresh fish $=$ Values of feed cost $/ \mathrm{Kg}$ fresh fish $/$ the minimum value of the same parameter

Feed cost $/ 1 \mathrm{Kg}$ gain $(\mathrm{LE})=$ Feed intake per $\mathrm{kg}$ gain $(\mathrm{FCR}) * \operatorname{cost} / \mathrm{kg} \operatorname{diet}(\mathrm{LE})$.

$\mathrm{ECR}=$ cost of diet $\left(\$ \mathrm{~kg}^{-1}\right) \times$ Feed Conversion Ratio $(\mathrm{FCR})$

\section{Statistical analysis}

One-way ANOVA and Duncan's, (1955) multiple range tests were calculated effects with a probability of $\mathrm{p}<0.05$ were considered significant. The data from the experiments were statistically analyzed using GLM (general linear model) procedure according to Statistical Analysis System (SAS 2004). However, data is presented untransformed to facilitate comparisons.

\section{RESULTS}

\section{Growth performance and feed utilization:}

Fish growth performance presented in Table 2, shows that all fish fed HP-DDG supplemented with Protease had higher growth than the control diet, suggesting that the using of the tested ingredient supplemented with protease resulted in higher growth than the control diet, suggesting that the using of HPDDG-supplemented with Protease enhanced the growth performance of seabass fingerlings. The 

protease and higher in diet (50\% HPDDG with protease) compared to other treatments. The fish recorded high survival rate $100 \%$ in all tested diets and there were no mortality observed in the experiment (Table 3). Moreover, feed intake, FCR, PER and PPV were significantly enhanced with the increasing HP-DDG 205 levels compared to fish fed the control diet (Table 3). The highest values of FCR, PER and PPV were recorded for fish fed 50\% HP-DDG-supplemented with Protease, while the lowest values were observed

207 for fish fed the control diet. The same trend was recorded for the highest values of FR and ER for fish 208 fed 40\% HP-DDG-supplemented with Protease (Table 3).

\section{Hematological parameters:}

The white blood cells $\left(10^{4}\right)$, red blood cells $\left(10^{6}\right)$, hemoglobin $\left(\mathrm{g} \mathrm{dI}^{-1}\right)$ and hematocrit $(\mathrm{Hct}, \%)$ supplemented with Protease diets (Table 4). The WBCs, RBCs, Hb and Hct were tended to increase with increasing dietary HP-DDG levels (Table 4).

\section{Biochemical parameters:}

Total plasma protein and globulin ( $\alpha$ Globulin, $\beta$ Globulin and $\gamma$ Globulin) were significantly higher in fish fed with the diets containing different levels of HP-DDG-supplemented with Protease 217 compared to the control fish (Table 5) and the peak value recorded in 50\% HP-DDG-supplemented with 218 Protease diet compared to all treatments, but an opposite trend was observed for the total plasma 219 Albumin. A similar increasing trend was observed for the Cholesterol, Triglyceride, Lysozyme and total antioxidant capacity (TAC) (Table 6). Levels of serum aspartate aminotransferase (AST), alanine aminotransferase (ALT) and alkaline phosphatase (ALP) parameters are presented in Table 7. The highest values of ALT, AST and ALP were estimated in Seabass fed the control diet compared to HP-DDGsupplemented with Protease. The results observed that with increasing dietary HP-DDG levels the values of ALT, AST and ALP decreased compared to fish fed the control experimental diet group. 
Histology of the intestine of sea bass fed control diet and different levels of HP-DDG are showed in Figures (1-4). The histological analysis revealed that $D$. labrax fed on the control basal diet showing decreasing in the intestinal villi length and width and some evidence of damage and enteritis in some neighboring mucosal folds (Figure 1).

Fish fed 30\% HP-DDG supplemented diet with Protease showed moderate improvement in the length of intestinal villi with few goblet cells in the lining epithelial (Figure 2). While, fish fed $40 \%$ HPDDG supplemented diet with Protease showed improvement in length and width of intestinal villi with more regular uniformity as well as active goblet cells and filled with abundant acidic mucin secretion, due to increase absorption surface by supplementing protease and thus influence the intestinal health (Figure 3). Seabass fed 50\% HP-DDG-supplemented diet with Protease showed moderate improvement in length and width of intestinal villi as well as goblet cells and filled with abundant acidic mucin secretion (Figure 4).

\section{Economic evaluation:}

Calculations of economic efficiency of the tested diets based on the cost of feed cost for one $\mathrm{kg}$ weight gain are shown in Table (8). The 50\% HPDDG diet with protease exhibited significantly lower feed intake, best FCR and ECR values compared with the other diets, while fish fed the control diet recorded the highest in total feed cost / $\mathrm{kg}$ fish gain.

\section{DISCUSSION}

High protein content of HP-DDG products make them even more attractive for inclusion in fish diets because protein is the most expensive nutrient component in aqua-feeds. In the present study, fish fed up to $50 \%$ of HP-DDG-supplemented with Protease exhibited and improved growth indicating that enzyme is beneficial for the growth of sea bass (Table 2), these results could be attributed to: i) the role

249 of protease to improve nutrient bioavailability and consequently enhance growth performance and feed 
addition of the enzymes, ii) HPDDG supplemented with exogenous enzymes improve the available

252 energy of HPDDG by degrading the fiber content and increasing the digestibility of nonstarch 253 polysaccharides (Barletta, 2012), iii) exogenous enzymes in HPDDG based diets by disrupting the cell wall matrix and enhancing the contact between digestive enzyme and cell content, which resulted in improved energy and nutrient digestibility (Wu et al., 2004). These results are consistent with Barletta (2012) who found that protease supplementation could degrade complex proteins in the diet into usable amino acids and peptides thereby resulting in improved protein digestibility and growth performance. In addition protease is capable of degrading grain storage proteins and liberating higher levels of available amino acids, energy and eliminate the effects of anti-nutritional factors in carnivorous fish diets containing high levels of plant-based feedstuffs resulting in improve performance (Dias et al., 2014; Gitoee et al., 2015). Growth responses of seabass fed enzyme protease supplemented diets were strongly related to enhance feed efficiency (Table 3). This indicates that the enzymes promoted feed intake in this group of fish, suggesting that they were effective in resisting the anti-nutritional effect of plant protein and increased growth. However, the mechanism of improving the feed intake in fish fed diets supplemented with enzymes is still unclear, but two possible explanations can be debated. One is the enhancement of palatability of the diets by free amino acids generated by protease activity enzyme (Carr et al. 1996) which resulted in higher feed intake in fish fed the diets supplemented with enzyme complex. Another explanation is the higher digestibility of nutrients in the diet. Debnath et al. (2005) reported that higher digestibility of dietary nutrients could lead faster gut passage of ingested feed. It was suggested that return of appetite is strongly correlated with rate of gastric evacuation of ingested food in fish (Lee et al. 2000). Faster digestion of ingested food could potentially promote feed intake of fish. The addition 272 of exogenous enzymes to aqua-feed has been reported to enhance the digestion of indigestible ingredients 273 in some species of fish and shrimp and it improve the growth performance such as Atlantic salmon (Carter 274 et al. 1994), black tiger shrimp Penaeus monodon (Buchanan et al. 1997) and silver perch Bidyanus 275 bidyanus (Stone et al. 2003; Yu et al., 2007). On contrary, Nalan et al. (2016) reported that dietary 
277 performance and FCR. Similarly, Dalsgaard et al. (2012) found that there were no differences in growth

278

279

280

281

282

283

284

285

286

287

288

289

290

291

292

293

294

295

296

297

298

299

parameters and FCR with the addition of protease to soybean meal in rainbow trout diet. The discrepancy in their results may be associated with many factors affect the action of dietary enzyme, such as diet composition and feed processing. If the basal diet had a high nutrition level which had satisfied the nutrition requirement of aquatic animals, the supplementation of protease would not show positive effects on growth, while the basal diet had a low nutrition level or consisted of ingredients with relatively low quality, and the improvement of growth and nutrients utilization by dietary protease could be observed (Li et al., 2016).

Total serum protein is often used as an indicator of physiological condition in fish, as it is one of the most stable components of blood, and so an increase or decrease of total blood proteins, globulins and albumin has clinical relevance in fish (Peres et al., 2015). High plasma albumin and/or globulin has been related to stress, inflammatory, innate immune responses and feeding immunostimulants (Peres et al., 2015). Also higher levels of plasma non-specific humoral immune parameter, such as lysozyme and complement activity, have been used as indicative of immuno-enhancing properties to certain dietary compounds. In the present study, the hematological, biochemical and immune parameters WBC, RBC, $\mathrm{Hb}, \mathrm{PCV}$, total protein and globulin increased in fish diet containing HPDDG supplemented with protease enzymes compared with the control group (Table 4\&5). These results are consistent with Peatman and Beck, (2016) found that commercial catfish fed diets with high levels of phytase enzymes could significantly improve the concentration of RBC's, WBCs, PCV\% and $\mathrm{Hb}$ concentration as a result of phytase super dose fortification. The increase in hemoglobin concentration could be attributed to the higher oxygen consumption associated with more hemoglobin saturation and dissociation rates (Yahav et al., 1998). The serum albumin levels were significantly higher on the control diet without DDGS or enzyme supplementation (Table 5). These findings are in agreement with El-Katcha et al. (2014) who 

compared with broiler fed on the same diet without enzyme supplementation. and bile duct. The increasing activities of serum AST and ALT in fish may reveal the leakage of enzymes across damaged plasma membranes and/or rising synthesis of enzymes by the liver tissue (Yang and Chen, 2003). Thus, the activity of serum AST and ALT are used as important indicators to reflect the health of liver and their functions of the fish (Zhai et al., 2014) as well as it can be used to assess the health status and as stress indicators in fish (Satheeshkumar et al., 2010). In the present study increasing dietary HP-DDG levels the values of ALT, AST and ALP decreased compared to fish fed the control experimental diet group (Table 6), while the levels of Cholesterol, Triglyceride, lysozyme, TAC increased (Table 7), suppress the release of liver damage enzymes such as AST and ALT into plasma as stated previously by (Akrami et al. 2015). Also, the present results are consistent with (Shelby et al 2007) who found that Nile tilapia fed distillers dried grains with soluble improved immune, liver function and disease resistance. Similarly, Niamat (2017) found that Japanese quail fed diets partially or totally replaced yellow corn with DDGS recorded lower activities of AST and ALT compare to the control group. On Contrary, El-Saidy and Gaber (2003) showed that AST and ALT were not significantly affected by dietary contained 10, 15 and 20\% DDGs. The present results are consistently with previous research conducted by (El-Saidy and Gaber., 2003) using DDGS in Nile tilapia and concluded that DDGS 318 improve liver function of seabass. intestines of seabass fed HPDDG supplemented with protease diets compared to the control diet without DDGS or protease (Figure 1). The intestines of the fish showed intact epithelial barrier with well 322 organized villi-like mucosal folds, abundant IELs and goblet cells. The fish intestines displayed healthy 323 brush border with well organised and tightly packed microvilli revealing no signs of damage (Figure 2, $3243 \& 4)$. However, the microvilli of the brush border of seabass fed control without protease 
supplementation appeared to be less tightly packed (Figure 1). Consequently, the microvilli density of the fish intestines was significantly different amongst seabass fed the experimental diets; the microvilli density of seabass fed the DDGS diets supplemented with protease were significantly higher $(\mathrm{P}<0.05)$ than that of seabass fed the control without phytase. In terms of gastrointestinal morphology, there was no significant difference in mid-intestine with respect to perimeter ratios, goblet cells levels and IELs levels, but significantly higher microvilli density (a measure of absorptive intestinal surface area) was observed in seabass fed diets supplemented with protease (Figure 1 - 4). This is in line with improved growth performance and may have been a contributory factor to the observed growth parameters (Adeoye et al., 2016). In the study on rainbow trout by Zhang et al. (2012), activities of intestinal protease and gastric protease and structure of foregut tissue were improved by adding protease in to diet. In contrast to the aquacultural sector the use of enzymes seems to be evaluated adequately in terrestrial animal production, as it is used there since decades (Bedford, 2000). This is why the economic viability of enzymes products seems to be even more likely in the aquaculture sector, since most feed ingredients have high values of plant proteins compared to those of terrestrial animal farming. However, potentially adapted production and extrusion processes might be necessary and seem to be a major issue regarding the incorporation of enzymes in fish feeds.

In term of economic evaluation fish fed 50\%HPDDG with protease achieved best FCR and ECR values (Table 8) compared with the other diets, while fish fed the control diet without DDGS and protease supplementation recorded the highest in total feed cost $/ \mathrm{kg}$ fish gain. These results are consistent with Alam et al. (2003) who observed that feed cost per kg live weight was reduced by addition of exogenous enzymes in broiler diet. In addition, Khan et al. (2006) concluded that enzymes supplementation is more feasible and economical to obtain maximum profitability from broiler production. They also reported that enzyme supplementation decreased the relative cost of broiler feeds by 4 to $18 \%$ compared to other diets without enzyme supplement. Moreover, Peric et al. (2008) found that in regard to positive economical 
349 effect, it is obvious that increase of cost of feed occurring because of the addition of enzyme, was annulled

350 through increase of body weight of chickens and improved feed conversion.

351 Acknowledgements

352

The authors are grateful for all the support from the National Institute of Oceanography and

353 Fisheries (NIOF) and Academy of Scientific Research and Technology (ASRT) for financial supported

354 under project No. 1332 title: The national campaign to promote the fish feed industry in Egypt, especially

355 for small and medium-producers, within the special grants program for national campaigns to promote 356 food production in Egypt 2016-2018. The authors would like to thank the scientists at fish nutrition 357 research laboratory teams for their kind assistance.

358

359

360

361

362

363

364

365

366

367

368

369

370

371

372

373

374

375

376

377

378 


\section{REFERENCES}

Adeoyea, A.A., Jaramillo-Torres, A., Fox, S.W., Merrifield, D.L., Davies S.J. (2016). Supplementation of formulated diets for tilapia (Oreochromis niloticus) with selected exogenous enzymes: Overall performance and effects on intestinal histology and microbiota. Animal Feed Science and Technology. 215, 133-143.

Akrami, R., Gharaei, A., Mansour, M.R. and Galeshi, A. 2015. Effects of dietary onion (Allium cepa) powder on growth, innate immune response and hemato-biochemical parameters of beluga (Huso huso Linnaeus, 1754) juvenile. Fish \& Shell. Immun. 45, 828-834.

Alam, M. J., M. A. R. Howlider, M. A. H. Pramanik and M. A. Haque (2003). Effect of exogenous enzyme in diet on broiler performance. International Journal of Poultry Science, 2 (2):168-173.

Ambasankar, K., Ahmad Ali, S., Syamadayal, J.2009. Nutritional Requirements of Asian Seabass, Lates calcarifer. In: Course manual: National Training on Cage Culture (Ed. Imelda Joseph et al.), Central Marine Fisheries Research Institute. December 14-23, 2009. Cochin.pp. 60-65.

Barletta, A. 2012. Current market and expected developments. Pages1-11 in Enzymes in Farm Animal Nutrition. 2nd ed. M. R. Bedford, and G. G. Partridge, eds. CABI, Cambridge, USA.

Bedford, M.R., 2000. Review article: exogenous enzymes in monogastric nutrition- their current value and future benefits. Anim. Feed Sci. Technol. 86, 1-13.

Bowyer, P. H. El-Haroun, E.R., Davies, S.J (2019). Dietary nucleotides enhance intestinal functional topography in European seabass (Dicentrarchus labrax).Aquaculture research. 20 (7): 19211930

Buchanan, J., H. Z. Sarac, D. Poppi, and R. T. Cowan (1997) Effects of enzyme addition to canola meal in prawn diets. Aquaculture,151, 29-35.

Carr, W. E. S., J. C. Netherton, R. A. Gleeson and C. D. Derby (1996) Stimulants of feeding behavior in fish: analyses of tissues of diverse marine organisms. Biol. Bull., 190, 149-160.

Carter, C.G., Houlihan, D.F., Buchanan, B., Mitchell, A.I. (1994). Growth and feed utilization efficiencies of seawater Atlantic salmon, Salmo salar L., fed a diet containing supplementary enzymes. Aquaculture and Fisheries Management.25, 37-46.

Castillo, S., Gatlin, D.M.(2015). Dietary supplementation of exogenous carbohydrase enzymes in fish nutrition: a review. Aquaculture, 435: 286-292.

Culling, C. F. (1983): Handbook of histopathologic and histochemical staining. 3rd Ed., Butterworth London.

Dalsgaard J, Verlhac V, Hjermitslev NH, Ekmann KS, Fischer M, Klausen M, Pedersen PB. 2012. Effects of exogenous enzymes on apparent nutrient digestibility in rainbow trout (Oncorhynchus 

mykiss) fed diets with high inclusion of plant-based protein. Anim Feed Sci Technol. 171:181191.

Danwitz, A. von, C.G.J. van Bussel, S.F. Klatt,C. Schulz. 2016. Dietary phytasesupplementation in rapeseed proteinbased diets influences growthperformance, digestibility and nutrientutilisation in turbot (Psetta maxima L.).Aquaculture 450: 405-411.

Debnath, D., A. K. Pal, N. P. Sahu, K. K. Jain, S. Yengkokpam, and S. C. Mukherjee (2005). Effect of dietary microbial phytase supplementation on growth and nutrient digestibility of Pangasius pangasius (Hamilton) fingerlings. Aquac. Res., 36, 180-187.

Dias, J., Rema, P., Nunes, C., Vogel, K., Verlhac, V., 2014. Efficacy of dietary protease supplementation on growth performance and nutrient digestibility and utilization of juvenile Nile tilapia fed low fishmeal diets with variable crude protein level, FeedInfo News.

Doumas, B.T., D. Bayse, R.J. Carter, T. Peters and R. Schaffer (1981). A candidate reference method for determination of total protein in serum: I Development and validation. Clin. Chem., 27, 16421650.

Drabkin, D. (1945): Spectrophotometric methods XIV. The crystographic and optical properties of the haemoglobin of man in comparison with those of other species. J.Biol.Chem.164, 703 - 723.

Duncan, D. B. (1955). Multiple range and multiple F test. Biometric, 11:1-42

El-Katcha, M. I., M. A. Soltan, H. F. El-Kaney and R. El-Sayed (2014). Growth performance, blood parameters, immune response and carcass traits of broiler chicks fed on graded levels of wheat instead of corn without or with enzyme supplementation. Alexandria Journal of Veterinary Sciences, 40:95-111.

Ellis, A. E. (1990): Lysozyme Assays. In: Techniques in Fish Immunology, Stolen, J. S., T. C. Fletcher, D. P. Anderson and W. B. van Muiswinkel (Eds.). Vol. 1, SOS Publications, New Jersey, USA, pp. 101-103.

El-Saidy, D.M.S.D. and Gaber, M.M.A. 2003.Replacement of fish meal with a mixture of different plant protein sources in juvenile Nile tilapia, Oreochromis niloticus(L.) diets. Aquaculture Research, 34:1119-1127

FAO, (2018). The State of World Fisheries and Aquaculture. Contributing to food security and nutrition for all. Rome. $200 \mathrm{pp}$.

Farhangi, M. and Carter, C.G. (2007). Effect of enzyme supplementation to dehulled lupin-based diets on growth, feed efficiency, nutrient digestibility and carcass composition of rainbow trout, Oncorhynchus mykiss (Walbaum). Aquacult. Res. 38: 1274-1282. 
Forster, I., D. A. Higgs, Dosanjh ,B. S., Rowshandeli, M. and Parr ,J. (1999). Potential for dietary phytase to improve the nutritive value of canola protein concentrate and decrease phosphorus output in rainbow trout (Oncorhynchus mykiss) held in $11^{\circ} \mathrm{C}$ fresh water. Aquaculture, 179:109-125.

Galaktionova L.P.; Molchanov A.V.; El'chaninova S.A. and Varshavskii B.I. (1998): Lipid peroxidation in patients with gastric and duodenal peptic ulcers - Klin. Lab. Diagn. 6: 10-14.

Gitoee, A., Janmohammadi, H., Taghizadeg, A., Rafat, S.A. (2015). "Effects of multi-enzyme on performance and carcass characteristics of broiler chickens fed corn-soybean meal basal diets with different metabolizable energy levels”.Journal of Applied Animal Research, 2015 Vol. 43, No. 3, 295-302.

Goda, A., Tarek Srour, Eglal Omar, Abdallah Mansour, Mohamed Baromh, Sherine Mohamed, Simon Davies and Ehab El-Haroun (2019). Appraisal of a high protein distiller's dried grain (DDG) in diets for European sea bass, Dicentrarchus labrax fingerlings on growth performance, haematological status and related gut histology. Aquaculture nutrition DOI: 10.1111/anu.12898

Hassaan, M., Davies, S., and El-Haroun, E. R. (2018a). Growth and physiological responses of Nile tilapia, Oreochromis niloticus to dietary fermented sunflower meal with Saccharomyces cerevisiae and Bacillus subtilis. Aquaculture, 495, 592-601.

Hassaan, M. S., Mahmoud, S. A., Jarmolowicz, S., El-Haroun, E. R., Mohammady, E. Y., and Davies, S. J. (2018b). Effects of dietary baker's yeast extract on the growth, blood indices and histology of Nile tilapia (Oreochromis niloticus L.) fingerlings. Aquaculture Nutrition, 24(6), 1709-1717.

Hassaan, M. S., El-Sayed, A. I. M., Soltan, M. A., Iraqi, M. M., Goda, A. M., Davies, S. J. and Ramadan, H. A. (2019). Partial dietary fish meal replacement with cotton seed meal and supplementation with exogenous protease alters growth, feed performance, hematological indices and associated gene expression markers (GH, IGF-I) for Nile tilapia, Oreochromis niloticus. Aquaculture, 503, $282-292$.

Hernandez, F., M.Lopez, S. Martinez, M. D. Megias, P. Catala, and J. Madrid (2012). Effect of lowprotein diets and single sex on production performance, plasma metabolites, digestibility, and nitrogen excretion in 1- to 48-day-old broilers. Journal of Poultry Science, 91:683-692.

Kamran, Z., M. Aslam Mirza, Ahsan-ul-Haq and S. Mahmood (2004). Effect of decreasing dietary protein levels with optimal amino acids profile on the performance of broilers. Pakistan Veterinary Journal, 24(4): 165-168.

Kawsar, A., Ghaly., A., Attiat, H., El-Bogdady, S. A., Abd El-Latif, A.S., and Abd ElHameed, A.S. (2017). Effects of using DDGS and Avizyme enzyme in the broiler diets on some physiological response. Egyptian Poultry Science Journal. Vol (37) (II) :363-377. 
Khan, S. H., R. Sardar and B. Siddique (2006). Influence of enzymes on performance of broilers fed Sunflower-corn based diets. Pakistan Veterinary Journal, 26 (3): 109-114.

Perić, L, N. Milošević1, M. Đukić-Stojčić1, S. Bjedov1, V. Rodić (2008). Effect of enzymes on performances of broiler chickens. Biotechnology in Animal Husbandry, 24 (5-6): 45-51.

Lee, S., U. Hwang, and S. H. Cho (2000) Effects of feeding frequency and dietary moisture content on growth, body composition and gastric evacuation of juvenile Korean rockfish (Sebastesschlegeli). Aquaculture,187, 399-409.

Liu, K. S. (2011). Chemical composition of distillers grains, a review. J. Agric. Food Chem. 59, 15081526.

Magalhães, R., Coutinho, P., Ferreira, P.P., Aires, T., Teles, A.,O., Peres, H (2015). Corn distiller's dried grains with solubles: Apparent digestibility and digestive enzymes activities in European seabass (Dicentrarchus labrax) and meagre (Argyrosomus regius). Aquaculture 443 (2015) 9097

Mathlouthi, N., Lallès, J.P., Lepercq, P., Juste, C. and Larbier, M. (2002). Xylanase and betaglucanasesupplementation improve conjugated bile acid fraction in intestinal contents and increase villus size ofsmall intestine wall in broiler chickens fed a rye-based diet. J. Anim. Sci, $80: 2773-2779$.

Nalan Ozgur Yigit, Seval Bahadir Koca, Behire Isil Didinen and Ibrahim Diler.(2016). Effect of protease and phytase supplementation on growth performance and nutrient digestibility of rainbow trout (Oncorhynchus mykiss, Walbaum) fed soybean meal-based diets. Journal of Applied Animal Research. 0971-2119 (Print) 0974-1844 (Online) Journal homepage: http://www.tandfonline.com/loi/taar20.

National Research Council (NRC). (1993). Nutrient requirements of fish. Washington, D.C., National Academy Press, 114 pp.

Niamat M. El- Abd (2017) yellow corn replaced by distillers dried grains with solubles (DDGS) of dietary Japanese quail. Egyptian journal of poultry science, (37)(II): (451-460)

Peatman, E. and Beck, B.H. 2016. From floor sweepings to fish flesh - phytase superdosing in the US catfish industry. Phytate destruction-consequences for precision animal nutrition. pp. 237-250.

Peres, H., Costas, B., Perez-Jimenez, A., Guerreiro, I., Oliva-Teles, A., (2015). Reference values for selected hematological and serum biochemical parameters of Senegalese sole (Solea senegalensis Kaup, 1858) juveniles under intensive aquaculture conditions. J. Appl. Ichthyol. 31, 65-71. http://onlinelibrary.wiley.com/doi/10.1111/jai.12641/abstract

Reinhold, R.R. (1953). Determination of serum albumin. Clinical Chem., 21, 1370-1372. 
Salama, F. A.; tonsy, H. D.; Labib, E. M.; Mahmoud, S. H. and Zaki, M. A. (2010). Nutrtional studies on partial and total replacement of soybean meal by distillers dried grain with soluble (DDG'S) in diet for Nile tilapia (Oreochromis niloticus). Egyptian Journal of Nutrition and Feeds, 13 (1): 165-176.

Satheeshkumar, P., Ananthan, G., Senthilkumar, D., Khan, A.B., Jeevanantham, K. 2010. Comparative investigation on haematological and biochemical studies on wild marine teleost fishes from Vellar estuary, southeast coast of Ind. Comp. Clin. Patho. 21, 275-281.

SAS, 2004. Statistical Analysis System User's Guide (version 9). SAS Institute, Inc., Cary, North Carolina, USA.

Shelby, R.A., Chhorn, L., Mediha, Y.A., Klesius, P, H. (2008). Effect of distillers dried grains with solubles-incorporated diets on growth, immune function and disease resistance in Nile tilapia Oreochromis niloticus. Journal of aquaculture research, 39, 351-353

Soltan, M.A. (2009). Effect of dietary fish meal replacement by poultry by-product meal with different grain source and enzyme supplementation on performance, feces recovery, body composition and nutrient balance of Nile tilapia. Pakistan J.Nutr, 8:395-407.

Stone, D.A.J., G. L. Allan, and A. J. Anderson (2003) Carbohydrate utilization by juvenile silver perch,Bidyanusbidyanus(Mitchell) IV. Can dietary enzymes increase digestible energy from wheatstarch, wheat and dehulledlupin?Aquac. Res., 34,135-147.

Stoskopf, M. K. (1993): Fish Medicine W.B. Saunders Comp. Philadelphia.

Wu, Y.B. Ravindran, V. Thomas, D.G. Birtles, M.J. and Hendriks, W.H. 2004. Influence of phytase and xylanase, individually or in combination, on performance, apparent metabolisable energy, digestive tract measurements and gut morphology in broilers fed wheat-based diets containing adequate level of phosphorus. British Poultry Science45:76- 84.

Yahav, S.; D. Lugar; A. Cahaner; M. Dotan; M. Ruzan ; and S. Hurwitz, 1998. Thermoregulation in naked neck chickens subjected to different ambient temperatures. British Poultry Science. (39): 133-138.

Yoo, G. Y., Wang, X. J., Choi, S. M. and Han, K. M. (2005). Dietary microbial phytase increased the phosphorus digestibility in juvenile Korean rockfish Sebastes schlegeli fed diets containing soybean meal. Aquaculture, 243: 315-322.

Yang, J.L., Chen, H.C. (2003). Serum metabolic enzyme activities and hepatocyte ultrastructure of common carp after gallium exposure. Zoolo. Studi. 42, 455-461. 
541 Youssef, Amani A.W.; N.A. Abd El-azeem; E.F. El-Daly; and M.M. El-Monairy. (2013). The impact of 542 feeding graded levels of distillers dried grains with soluble (DDGS) on broiler performance, 543 hematological and histological parameters. Asian Journal of Poultry Science. 7 (2): 41-54.

544 Yu B., Wu S.T., Liu C.C., Gauthier R. and Chiou P.W.S. (2007). Effects of enzyme inclusion in a maize545 soybean diet on broiler performance. Animal Feed Science and Technology 134:283-294.

546 Zhai, S.W., Lu, J.J., Chen, X.H. 2014. Effects of dietary grape seed proanthocyanidins on growth 547 548 549 550 performance, some serum biochemical parameters and body composition of tilapia (Oreochromis niloticus) fingerlings. Itali. J. of Anim. Sci. 13, 3357.

Zhang, J.J., Li, X.Q., Leng, X.J., Han, Z.Y. and Zhang, F.G. (2012). Effects of supplemental protease on growth and intestinal tissue structure in rainbow trout Oncorhynchus mykiss. J. Dalian Ocean 551 Univ., 27, 534-538.

552 
1 Table (1): Formulation and chemical composition of the experimental diets $(\mathrm{g} / \mathrm{kg})$

\begin{tabular}{lcccc}
\hline Ingredients & Control & $\mathrm{P}_{30 \%}$ & $\mathrm{P}_{40 \%}$ & $\mathrm{P}_{50 \%}$ \\
\hline Fish meal 68 \% CP & 300 & 300 & 300 & 300 \\
Soy bean meal 47\% CP & 375 & 262.5 & 225 & 187.5 \\
Corn gluten 60\% CP & 90 & 90 & 90 & 90 \\
Rice bran 12\% CP & 65 & 50 & 50 & 50 \\
Wheat midllings 13\% CP & 70 & 83.8 & 84.8 & 85.8 \\
HP-DDG (BP50) & 0 & 112.5 & 150 & 187.5 \\
Soy bean oil & 41 & 42 & 41 & 41 \\
Fish oil & 47.8 & 48 & 48 & 47 \\
Di-calcium phosphate & 8 & 8 & 8 & 8 \\
Vit. and Min. premix ${ }^{1}$ & 2 & 2 & 2 & 2 \\
Vitamin. C* & 0.2 & 0.2 & 0.2 & 0.2 \\
Protease (PROXYM ULTRA $\left.{ }^{\circledR}\right)$ & 1 & 1 & 1 & 1 \\
Total & 1000 & 1000 & 1000 & 1000 \\
\hline & Chemical composition $(\mathrm{g} / \mathrm{kg})$ & & 446 \\
\hline Crude protein (CP) & 448.6 & 448.8 & 449.7 & 128.9 \\
Ether extract (EE) & 125.6 & 131 & 129.8 & 278.6 \\
Nitrogen free extract (NFE) & 283.3 & 257 & 266.5 & 114.5 \\
Ash & 110 & 120 & 120 & 20.96 \\
Gross energy (GE; MJ/kg) & 20.98 & 20.93 & 20.91 & $\mathrm{~B}$ \\
\hline
\end{tabular}

${ }^{1}$ Vitamins and minerals mixture each $1 \mathrm{Kg}$ of mixture contains: $12 \mathrm{~m} . \mathrm{IU}$ vit. A, $12 \mathrm{mIU}$ vit. $\mathrm{D}_{3}$,

$310 \mathrm{~g}$ vit. E, $2 \mathrm{~g}$ vit. $\mathrm{K}, 1 \mathrm{~g}$ vit. $\mathrm{B}_{1}, 5 \mathrm{~g}$ vit. $\mathrm{B}_{2}, 1.5 \mathrm{~g}$ vit. $\mathrm{B}_{6}, 10 \mathrm{mg}$ vit. $\mathrm{B}_{12}, 30 \mathrm{~g}$ niacin, $1000 \mathrm{mg}$ folic

4 acid, 50mg biotin, $10 \mathrm{~g}$ banathonic acid, 50g zinc, 30g iron, $60 \mathrm{~g}$ manganese, $10 \mathrm{~g}$ copper, $100 \mathrm{mg}$ 5 cobalt, $100 \mathrm{mg}$ selenium, $1000 \mathrm{mg}$ iodine.

$6 \quad{ }^{2}$ NFE: nitrogen-free extract calculated using the following equation: NFE $=100$ (crude protein + 7 ether extract + crude fiber + ash).

$8{ }^{3}$ Gross energy (GE) = Calculated using gross calorific values of $23.63,39.52$ and $17.15 \mathrm{KJ} \mathrm{g}^{-1}$

9 for protein, fat and carbohydrate, respectively according to (NRC, 1993).

10 *Ascorbyl Phosphate 
17 Table (2): Growth performances of European sea bass fed the experimental diets (means $\pm \mathrm{SE}$ ).

\begin{tabular}{lcccc}
\hline Diets & IBW $\left(\mathrm{g} \mathrm{fish}^{-1}\right)$ & FBW $\left(\mathrm{g} \mathrm{fish}^{-1}\right)$ & WG $\left(\mathrm{g} \mathrm{fish}^{-1}\right)$ & SGR (\%/day) \\
\hline Control & $7.47 \pm 0.06$ & $15.57 \pm 0.81^{\mathrm{b}}$ & $8.10 \pm 0.79^{\mathrm{b}}$ & $1.31 \pm 0.09^{\mathrm{b}}$ \\
$\mathrm{P}_{30 \%}$ & $7.53 \pm 0.12$ & $16.80 \pm 0.70^{\mathrm{ab}}$ & $9.27 \pm 0.60^{\mathrm{ab}}$ & $1.43 \pm 0.05^{\mathrm{ab}}$ \\
$\mathrm{P}_{40 \%}$ & $7.43 \pm 0.06$ & $17.07 \pm 0.45^{\mathrm{ab}}$ & $9.63 \pm 0.40^{\mathrm{ab}}$ & $1.48 \pm 0.04^{\mathrm{ab}}$ \\
$\mathrm{P}_{50 \%}$ & $7.43 \pm 0.06$ & $19.28 \pm 0.63^{\mathrm{a}}$ & $11.85 \pm 0.57^{\mathrm{a}}$ & $1.70 \pm 0.05^{\mathrm{a}}$ \\
\hline
\end{tabular}

18 Values are mean \pm SD of triplicate analyses. Means in the same column bearing different

19 superscript differ significantly $(\mathrm{P} \leq 0.05)$.

20 IBW, initial body weight; FBW, Final body weight; WG, weight gain ; FCR, feed conversion ratio

21 and SGR, specific growth rate.

22

23

24

25

26

27

28

29

30

31

32

33

34

35

36

37

38

39

40

41

42

43

44

45

46

47

48

49

50

51

52

53

54

55

56 
57 Table (3): Feed efficiency of European sea bass fed the experimental diets (means \pm SE).

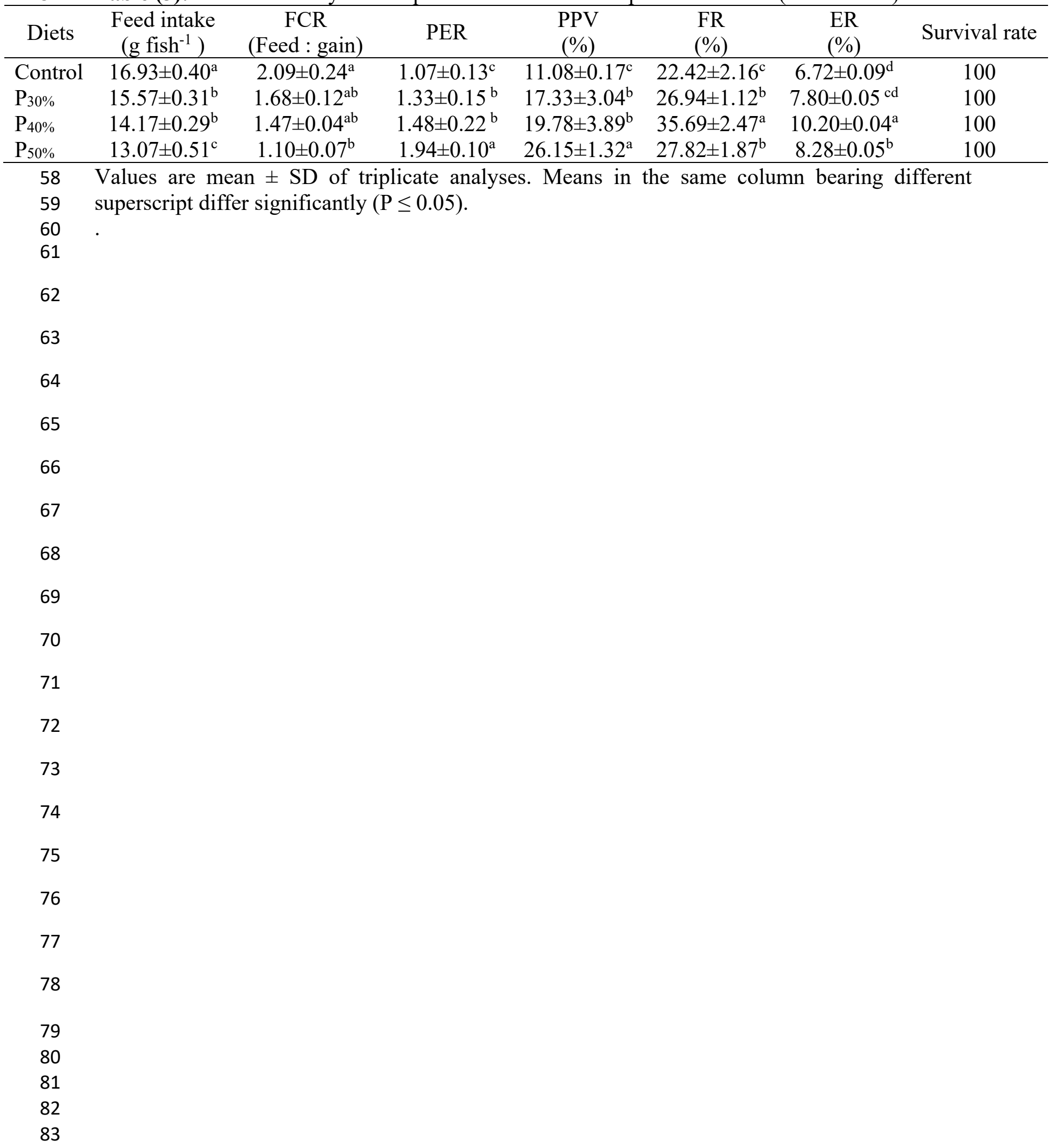


84 Table (4): Hematological parameters of European sea bass fed the experimental diets (means \pm 85 SE).

\begin{tabular}{lcccc}
\hline Diets & WBCs $\left(10^{4}\right)$ & RBCs $\left(10^{6}\right)$ & Hb $\left(\mathrm{g} \mathrm{dL}^{-1}\right)$ & Hct $(\%)$ \\
\hline Control & $23.95 \pm 0.45^{\mathrm{d}}$ & $1.51 \pm 0.03^{\mathrm{c}}$ & $8.10 \pm 0.16^{\mathrm{c}}$ & $20.21 \pm 0.18^{\mathrm{c}}$ \\
$\mathrm{P}_{30 \%}$ & $26.98 \pm 0.29^{\mathrm{c}}$ & $1.89 \pm 0.06^{\mathrm{b}}$ & $9.27 \pm 0.11^{\mathrm{b}}$ & $23.66 \pm 0.14^{\mathrm{b}}$ \\
$\mathrm{P}_{40 \%}$ & $31.42 \pm 1.50^{\mathrm{b}}$ & $2.24 \pm 0.13^{\mathrm{ab}}$ & $10.64 \pm 0.36^{\mathrm{ab}}$ & $26.08 \pm 0.18^{\mathrm{ab}}$ \\
$\mathrm{P}_{50 \%}$ & $38.99 \pm 1.03^{\mathrm{a}}$ & $2.81 \pm 0.03^{\mathrm{a}}$ & $11.32 \pm 0.08^{\mathrm{a}}$ & $27.62 \pm 0.10^{\mathrm{a}}$ \\
\hline
\end{tabular}

86 Values are mean \pm SD of triplicate analyses. Means in the same column bearing different

87 superscript differ significantly $(\mathrm{P} \leq 0.05)$.

88 WBCs, white blood cells; RBCs, red blood cells; Hb, Hemoglobin; Hct \%, Hematocrit.

90

91

92

93

94

95

96

97

98

99

100

101

102

103

104

105

106

107

108

109

110

111 
112 Table (5): Biochemical parameters of European sea bass fed the experimental diets (means $\pm \mathrm{SE}$ ).

\begin{tabular}{lcccccc}
\hline Diets & $\begin{array}{c}\text { Total protein } \\
\left(\mathrm{g} \mathrm{dL}^{-1}\right)\end{array}$ & $\begin{array}{c}\text { Albumin } \\
\left(\mathrm{g} \mathrm{dL}^{-1}\right)\end{array}$ & $\begin{array}{c}\text { Globulin } \\
\left(\mathrm{g} \mathrm{dL}^{-1}\right)\end{array}$ & $\begin{array}{c}\alpha \text { Globulin } \\
(\mathrm{mg} / \mathrm{dl})\end{array}$ & $\begin{array}{c}\beta \text { Globulin } \\
(\mathrm{mg} / \mathrm{dl})\end{array}$ & $\begin{array}{c}\gamma \text { Globulin } \\
(\mathrm{mg} / \mathrm{dl})\end{array}$ \\
\hline Control & $3.50 \pm 0.04^{\mathrm{c}}$ & $2.02 \pm 0.13^{\mathrm{a}}$ & $1.48 \pm 0.10^{\mathrm{d}}$ & $0.36 \pm 0.01^{\mathrm{c}}$ & $0.34 \pm 0.01^{\mathrm{c}}$ & $0.74 \pm 0.02^{\mathrm{c}}$ \\
$\mathrm{P}_{30 \%}$ & $3.60 \pm 0.01^{\mathrm{c}}$ & $1.80 \pm 0.04^{\mathrm{b}}$ & $1.80 \pm 0.03^{\mathrm{bc}}$ & $0.44 \pm 0.03^{\mathrm{b}}$ & $0.40 \pm 0.01^{\mathrm{b}}$ & $0.78 \pm 0.01^{\mathrm{b}}$ \\
$\mathrm{P}_{40 \%}$ & $3.90 \pm 0.04^{\mathrm{b}}$ & $1.62 \pm 0.04^{\mathrm{c}}$ & $2.29 \pm 0.01^{\mathrm{b}}$ & $0.53 \pm 0.02^{\mathrm{a}}$ & $0.47 \pm 0.05^{\mathrm{a}}$ & $0.80 \pm 0.06^{\mathrm{b}}$ \\
$\mathrm{P}_{50 \%}$ & $4.15 \pm 0.02^{\mathrm{a}}$ & $1.55 \pm 0.05^{\mathrm{d}}$ & $2.60 \pm 0.03^{\mathrm{a}}$ & $0.56 \pm 0.06^{\mathrm{a}}$ & $0.48 \pm 0.01^{\mathrm{a}}$ & $1.03 \pm 0.02^{\mathrm{a}}$ \\
\hline
\end{tabular}

113 Values are mean \pm SD of triplicate analyses. Means in the same column bearing different 114 superscript differ significantly $(\mathrm{P} \leq 0.05)$.

115

116

117

118

119

120

121

122

123

124

125

126

127

128

129

130

131

132

133

134

135

136

137

138

139

140

141

142

143

144

145

146

147

148

149

150

151 
152 Table (6): Biochemical parameters of European sea bass fed the experimental diets (means $\pm \mathrm{SE}$ ).

\begin{tabular}{lcccc}
\hline Diets & $\begin{array}{c}\text { Cholesterol } \\
\left(\mathrm{mg} \mathrm{dL}^{-1}\right)\end{array}$ & $\begin{array}{c}\text { Triglyceride } \\
\left(\mathrm{mg} \mathrm{dL}^{-1}\right)\end{array}$ & $\begin{array}{c}\text { Lysozyme } \\
\left(\mathrm{U} \mathrm{mg}^{-1} \text { protein }^{2}\right.\end{array}$ & $\begin{array}{c}\text { TAC } \\
(\%)\end{array}$ \\
\hline Control & $147.04 \pm 1.91^{\mathrm{c}}$ & $142.40 \pm 6.75^{\mathrm{d}}$ & $1.91 \pm 0.04^{\mathrm{d}}$ & $8.23 \pm 0.13^{\mathrm{b}}$ \\
$\mathrm{P}_{30 \%}$ & $175.84 \pm 4.04^{\mathrm{b}}$ & $162.71 \pm 6.26^{\mathrm{c}}$ & $2.90 \pm 0.04^{\mathrm{c}}$ & $8.89 \pm 0.40^{\mathrm{b}}$ \\
$\mathrm{P}_{40 \%}$ & $191.80 \pm 5.43^{\mathrm{b}}$ & $215.77 \pm 2.26^{\mathrm{b}}$ & $3.88 \pm 0.08^{\mathrm{bc}}$ & $9.92 \pm 0.49^{\mathrm{ab}}$ \\
$\mathrm{P}_{50 \%}$ & $239.53 \pm 2.19^{\mathrm{a}}$ & $261.34 \pm 6.75^{\mathrm{a}}$ & $4.77 \pm 0.01^{\mathrm{a}}$ & $13.78 \pm 0.70^{\mathrm{a}}$ \\
\hline
\end{tabular}

153 Values are mean \pm SD of triplicate analyses. Means in the same column bearing different

154 superscript differ significantly $(\mathrm{P} \leq 0.05)$.

$155 \quad \mathrm{TAC}=$ Total antioxidant capacity.

156

157

158

159

160

161

162

163

164

165

166

167

168

169

170

171

172

173

174

175

176

177

178

179

180

181

182

183

184

185

186

187

188

189

190

191 
192

\begin{tabular}{lccc}
\multicolumn{4}{l}{ Table (7): Liver function of European sea bass fed the experimental diets (means \pm SE). } \\
\hline Diets & AST (IU/L) & ALT (IU/L) & ALP (IU/L) \\
\hline Control & $35.28 \pm 1.51^{\mathrm{a}}$ & $30.84 \pm 0.86^{\mathrm{a}}$ & $17.50 \pm 0.47^{\mathrm{a}}$ \\
$\mathrm{P}_{30 \%}$ & $32.77 \pm 0.59^{\mathrm{b}}$ & $28.19 \pm 1.38^{\mathrm{b}}$ & $17.07 \pm 0.42^{\mathrm{a}}$ \\
$\mathrm{P}_{40 \%}$ & $26.23 \pm 1.54^{\mathrm{c}}$ & $23.87 \pm 0.76^{\mathrm{c}}$ & $17.32 \pm 0.04^{\mathrm{a}}$ \\
$\mathrm{P}_{50 \%}$ & $20.90 \pm 0.34^{\mathrm{d}}$ & $20.22 \pm 1.42^{\mathrm{d}}$ & $15.86 \pm 0.86^{\mathrm{b}}$ \\
\hline
\end{tabular}

193 Values are mean \pm SD of triplicate analyses. Means in the same column bearing different 194 superscript differ significantly $(\mathrm{P} \leq 0.05)$.

195 HP-DDG = high protein distiller's dried grains; AST= serum aspartate aminotransferase, ALT= 196 alanine aminotransferase and $\mathrm{ALP}=$ alkaline phosphatase

197

198

199

200

201

202

203

204

205

206

207

208

209

210

211

212

213

214

215

216

217

218

219

220

221

222

223

224 
225 Table (8): Economical evaluation of European sea bass fed the experimental diets (means $\pm \mathrm{SE}$ ).

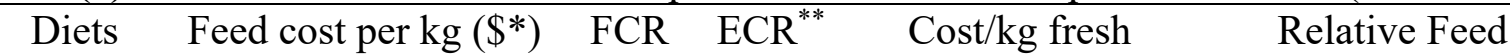

\begin{tabular}{lccccc} 
& & & $\left(\$^{*}\right)$ & fish $\left(\$^{*}\right)$ & cost $/ \mathrm{kg}$ \\
\hline Control & 0.75 & 2.09 & 1.57 & 0.75 & 100 \\
$\mathrm{P}_{30 \%}$ & 0.71 & 1.68 & 1.19 & 0.71 & 76.10 \\
$\mathrm{P}_{40 \%}$ & 0.67 & 1.47 & 0.98 & 0.67 & 62.83 \\
$\mathrm{P}_{50 \%}$ & 0.63 & 1.10 & 0.69 & 0.63 & 44.21 \\
\hline
\end{tabular}

$226 * 1 \$=17.8$ L.E. (Egyptian pound).

$227{ }^{* *} \mathrm{ECR}=$ cost of diet $\left(\$ \mathrm{~kg}^{-1}\right) \times$ Feed Conversion Ratio (FCR)

228 Price of $\mathrm{SBM}=8650$ L.E

229 Price of $\mathrm{HP}-\mathrm{DDG}=7600 \mathrm{LE}$

230

231

232 


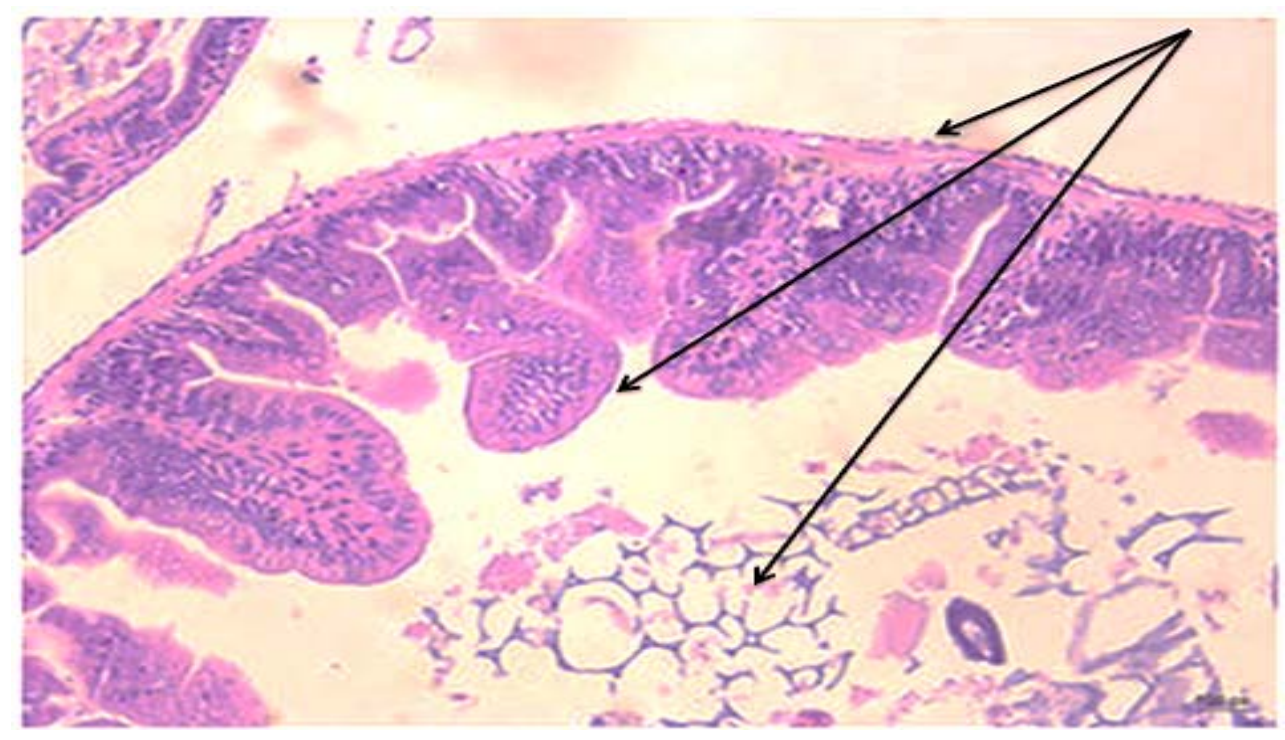

Figure (1): histological section of Intestinal tract of sea bass (feed on control basal diet) showing normal, intact intestinal wall and intestinal villi (Arrows) (H\&E X10). 

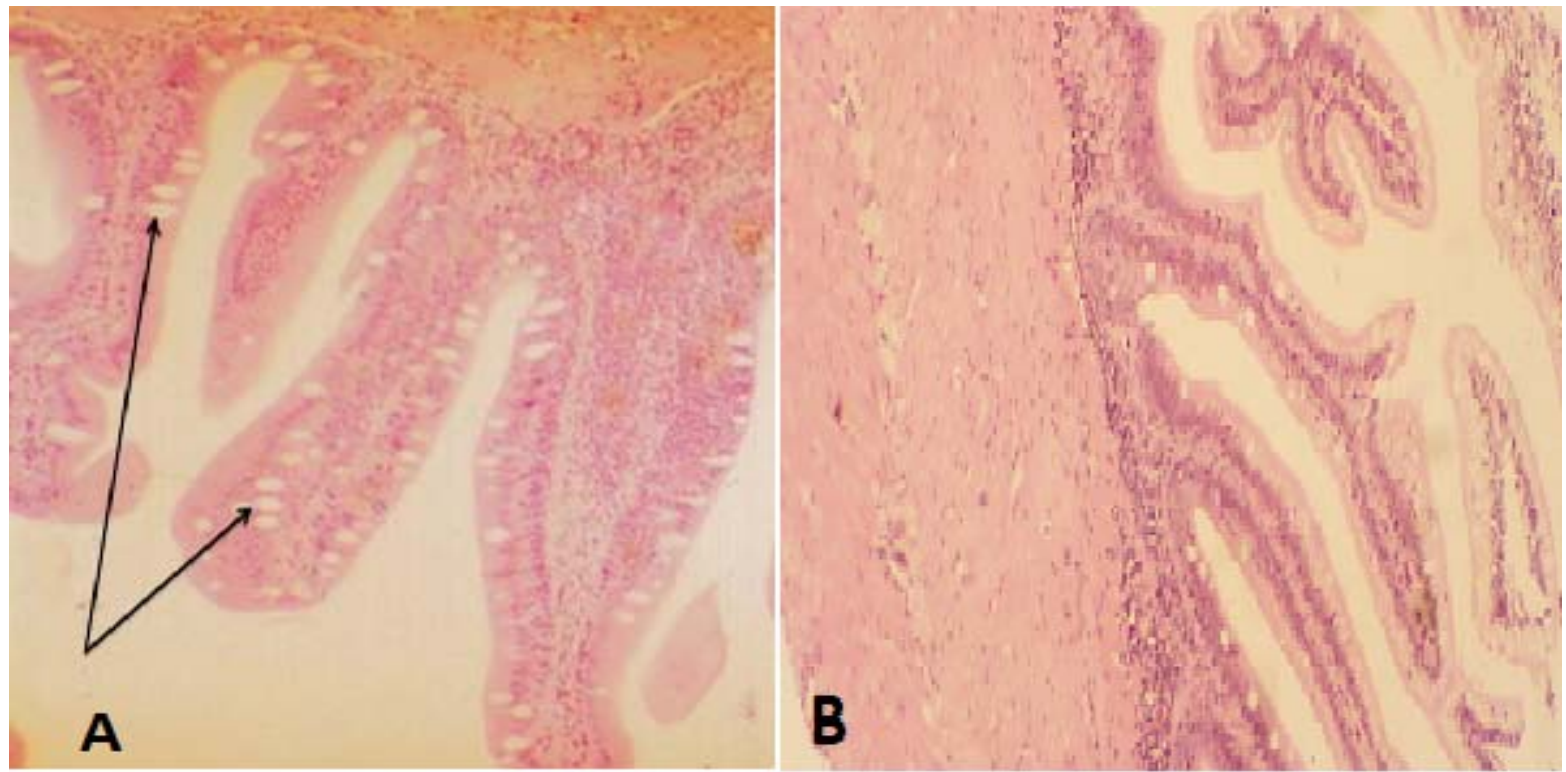

Figure (2): Photomicrograph of sea bass intestine stained with H\&E (AX40 and B X20), group (30\%HPDDG +Protease) showing increase in length and width of intestinal villi and mucosal folds (Arrow) as well as goblet cells (Stars). 

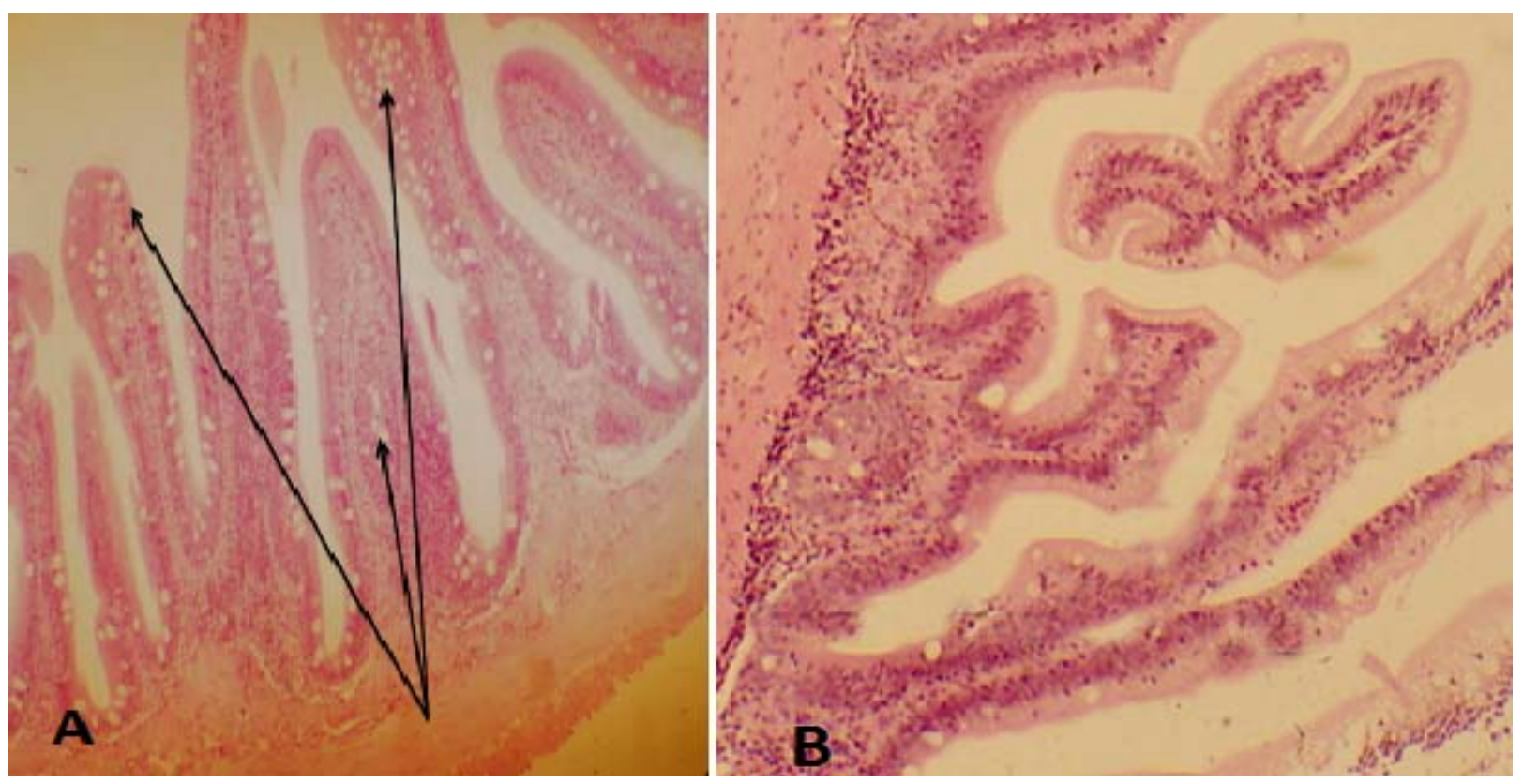

Figure (3). Photomicrograph of sea bass intestine stained with H\&E (AX40 and B X20), group (feed on 40\% HPDDG + Protease) showing increase in length and width of intestinal villi and mucosal folds (Arrow) as well as goblet cells (Stars). 

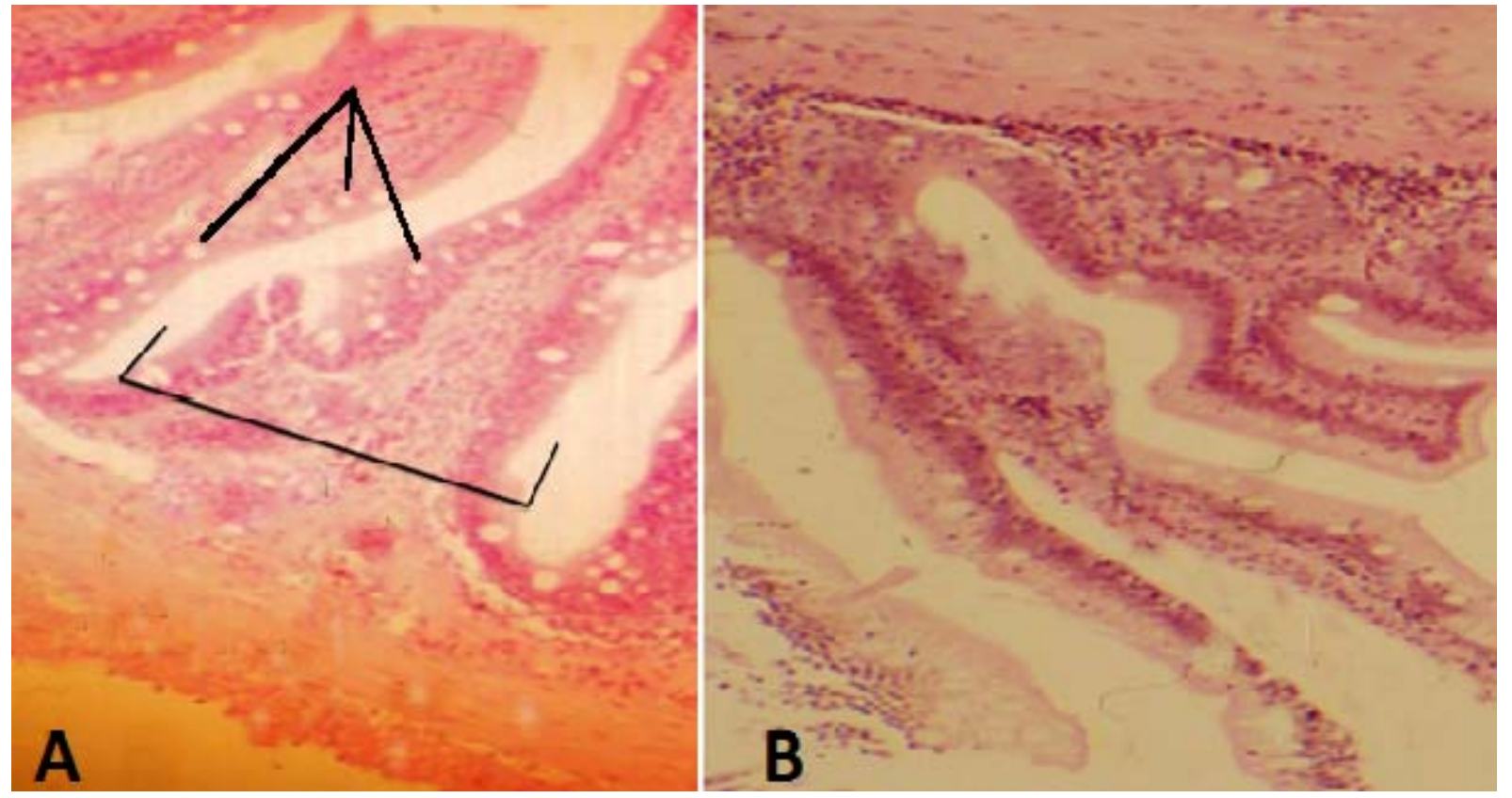

Figure (4). Photomicrograph of sea bass intestine stained with H\&E (AX40 and B X20), group (feed on 50\% HPDDG + Protease) showing increase in length and width of intestinal villi and thickness of intestinal mucosal (Arrow) as well as goblet cells (Star) 